\title{
Purification and Properties of Glutathione Peroxidase from Mucor hiemalis
}

\author{
Kazuo Aisaka, Takayuki Uwajima and Osamu Terada \\ Tokyo Research Laboratory, Kyowa Hakko Kogyo Co., \\ Machida-shi, Tokyo 194, Japan
}

Received December 7, 1982

\begin{abstract}
Selenium-independent glutathione peroxidase was purified from a cell-free extract of Mucor hiemalis by ammonium sulfate fractionation, column chromatographies on DEAE-Sephadex and hydroxylapatite, and gel filtration on Bio-Gel P-100. The purified enzyme was homogeneous on ultracentrifugation. The enzyme had a molecular weight of 45,000 and an isoelectric point of 5.2. The enzyme could reduce cumene hydroperoxide and $t$-butyl hydroperoxide, but could not reduce hydrogen peroxide. The enzyme was highly specific for glutathione as a hydrogen donor. Mucor glutathione peroxidase was proved to be different from mammalian selenium-dependent glutathione peroxidase I and selenium-independent glutathione peroxidase II in some physicochemical and enzymatic properties.
\end{abstract}

In the previous studies, ${ }^{1,2)}$ Mucor hiemalis was found to form a large quantity of selenium-independent glutathione peroxidase (EC 1.11.1.9) in the mycelium, and the cultural conditions for the production of glutathione peroxidase were described. The present paper describes the purification and characterization of glutathione peroxidase from $M$. hiemalis, and its comparison with mammalian seleniumdependent glutathione peroxidase I and selenium-independent glutathione peroxidase II.

\section{MATERIALS AND METHODS}

Microorganism and cultural conditions. The culture of Mucor hiemalis was conducted in a 300-liter fermentor. The medium composition and cultural conditions were as described previously. ${ }^{2)}$

Enzyme assay. Glutathione peroxidase activity was assayed by the following two methods.

(I) Coupled enzymatic method. The enzyme activity was assayed by determining the oxidized glutathione (GSSG) formed by the peroxidase with glutathione reductase (EC 1.6.4.2), as described perviously. ${ }^{2)}$ This method was used throughout the purification procedures and for most investigations of the enzymatic properties. One enzyme unit was defined as the amount of enzyme which oxidized $1 \mu \mathrm{mol}$ of glutathione per min, and specific activity was expressed as the enzyme units per $\mathrm{mg}$ of protein.

(II) DTNB method. For the sulfhydryl substrate specificity and some inhibition experiments, the enzyme activity was assayed by determining the decrease of sulfhydryl compounds with Ellman's reagent, 5,5'-dithiobis-2nitrobenzoic acid (DTNB), according to the method of Sedlak and Lindsay. ${ }^{3)}$ The reaction mixture contained 3 $\mu \mathrm{mol}$ of cumene hydroperoxide, $3 \mu \mathrm{mol}$ of glutathione or an other sulfhydryl compound, $150 \mu \mathrm{mol}$ of potassium phosphate buffer, $\mathrm{pH} 7.0,3 \mu \mathrm{mol}$ of sodium azide, $3 \mu \mathrm{mol}$ of EDTA and a suitable amount of enzyme in a total volume of $3.0 \mathrm{ml}$.

Protein determination. Protein concentration was determined by the method of Lowry et al. ${ }^{4)}$ with bovine serum albumin as standard.

Ultracentrifugal analysis. A Hitachi UCA-1 analytical ultracentrifuge with double-sector cells and an RA-60 rotor were used for the sedimentation analysis. The temperature was maintained at $20^{\circ} \mathrm{C}$ throughout.

Amino acid analysis. The amino acid composition was analyzed with a Nihon Denshi Model 5AH automatic amino acid analyzer. The sample was hydrolyzed in $6 \mathrm{~N} \mathrm{HCl}$ in a sealed evacuated tube at $110^{\circ} \mathrm{C}$ for $20 \mathrm{hr}$.

Molecular weight determination. Gel filtration was performed according to the method of Andrews, ${ }^{5)}$ with a column $(2.5 \times 50 \mathrm{~cm})$ of Sephadex G-150 equilibrated with $0.01 \mathrm{M}$ potassium phosphate buffer, $\mathrm{pH} 6.0$, containing $0.1 \mathrm{M} \mathrm{KCl}$. Elution was performed with the same buffer. Myoglobin (mol. wt. 17,800), chymotrypsinogen (mol. wt. 
25,000), ovalbumin (mol. wt. 45,000), bovine serum albumin (mol. wt. 67,000) and alcohol dehydrogenase (mol. wt. 150,000) were used as molecular-weight markers. SDSpolyacrylamide gel electrophoresis was performed according to the method of Weber and Osborn, ${ }^{6)}$ with columns of $10 \%$ polyacrylamide gel containing $0.1 \%$ SDS. Electrophoresis was performed at a constant current of $8 \mathrm{~mA}$ per column. Cytochrome $c$ (mol. wt. 13,000), myoglobin, chymotrypsinogen, ovalbumin and bovine serum albumin were used as molecular-weight markers.

Isoelectric focusing. Isoelectric focusing was performed according to the method of Vesterberg and Svensson, ${ }^{7)}$ with carrier ampholytes ( $\mathrm{pH} 3.5 \sim 10$, LKB-Produkter $\mathrm{AB})$. After focusing at a constant potential of $900 \mathrm{~V}$ for $48 \mathrm{hr}$ at $3^{\circ} \mathrm{C}$, the column was carefully drained through the bottom tubing, and $2.0 \mathrm{ml}$ fractions were collected. Each fraction was tested for $\mathrm{pH}$, protein concentration and enzyme activity.

Chemicals. DEAE-Sephadex A-50 and Sephadex G-150 were purchased from Pharmacia Fine Chemicals, Sweden. Bio-Gel P-100 was purchased from Bio-Rad Laboratories, USA. Hydroxylapatite was prepared as described by Tiselius et $a .^{8)}$ Other chemicals were the best commercial products available.

\section{RESULTS}

\section{Purification of glutathione peroxidase}

All operations were carried out at $0 \sim 5^{\circ} \mathrm{C}$ unless otherwise specified, and all buffers used were potassium phosphate buffer, $\mathrm{pH}$ 6.0.

1. Preparation of cell-free extract. Washed mycelia (ca. $400 \mathrm{~g}$, wet weight) of $M$. hiemalis were suspended in $4,000 \mathrm{ml}$ of $0.01 \mathrm{M}$ buffer, and then disrupted with a Dyno Mill KDL (W. A. Bachofen, Switzerland). The cell debris was removed by centrifugation at $20,000 \times g$ for 20 $\min$.

2. Ammonium sulfate fractionation. The cellfree extract was brought to $70 \%$ saturation with ammonium sulfate, and the precipitate formed was removed by centrifugation at $20,000 \times g$ for $20 \mathrm{~min}$. The resultant supernatant solution was made to $90 \%$ saturation with ammonium sulfate, and the precipitate formed was collected by filtration using celite as a filter aid. The enzyme precipitate contained in the filter aid was extracted three times with $200 \mathrm{ml}$ of $0.01 \mathrm{M}$ buffer, and the extracts were dialyzed overnight against the same buf- fer. The dialyzed enzyme preparation was concentrated by ultrafiltration with a YM 10 membrane (Amicon Corp., USA).

3. DEAE-Sephadex column chromatography. The concentrate $(100 \mathrm{ml})$ was applied onto a DEAE-Sephadex A-50 column $(5.5 \times 50 \mathrm{~cm})$, previously equilibrated with $0.01 \mathrm{M}$ buffer. The column was washed first with the same buffer, and then the enzyme was eluted with a linear gradient of $\mathrm{NaCl}$, from 0 to $0.4 \mathrm{M}$. The active fractions were combined and concentrated by ultrafiltration. The concentrate was dialyzed overnight against $0.01 \mathrm{M}$ buffer.

4. Bio-Gel P-100 gel filtration. The dialyzed enzyme solution $(20 \mathrm{ml})$ was applied onto a Bio-Gel P-100 column $(5.5 \times 48 \mathrm{~cm})$, previously equilibrated with $0.01 \mathrm{~m}$ buffer. Elution of the enzyme was performed with the same buffer. The active fractions were combined and concentrated by ultrafiltration and dialyzed overnight against $0.01 \mathrm{~m}$ buffer.

5. Hydroxylapatite column chromatography. The dialyzed enzyme solution $(40 \mathrm{ml})$ was applied onto a hydroxylapatite column $(2.5 \times$ $11 \mathrm{~cm}$ ), previously equilibrated with $0.01 \mathrm{M}$ buffer. The column was washed first with the same buffer and then with $0.05 \mathrm{M}$ buffer. The enzyme was eluted with $0.10 \mathrm{M}$ buffer. The active fractions were combined and dialyzed overnight against $0.01 \mathrm{~m}$ buffer. The dialyzed enzyme was concentrated by ultrafiltration and stored at $-20^{\circ} \mathrm{C}$.

The results of purification are summarized in Table I. Glutathione peroxidase was purified about 2000-fold from the cell-free extract of $M$. hiemalis with a recovery of about $10 \%$ of the initial activity.

\section{Properties of glutathione peroxidase}

Homogeneity. The purified enzyme preparation showed a single and symmetrical moving peak on ultracentrifuge analysis (Fig. 1). The apparent sedimentation coefficient, $S_{20, w}$, was calculated to be 2.24 . The enzyme also gave a single protein band on polyacrylamide gel electrophoresis carried out at $\mathrm{pH} 8.3$, as described previously. ${ }^{1)}$

Amino acid composition. The amino acid 
Table I. Purification of Glutathione Peroxidase from $M$. hiemalis

\begin{tabular}{lcccc}
\hline \multicolumn{1}{c}{ Step } & $\begin{array}{c}\text { Total } \\
\text { protein } \\
(\mathrm{mg})\end{array}$ & $\begin{array}{c}\text { Total } \\
\text { activity } \\
\text { (units) }\end{array}$ & $\begin{array}{c}\text { Specific } \\
\text { activity } \\
(\mathrm{u} / \mathrm{mg})\end{array}$ & $\begin{array}{c}\text { Recovery of } \\
\text { activity } \\
(\%)\end{array}$ \\
\hline Cell-free extract & 62,700 & 6,350 & 0.10 & 100 \\
$\left(\mathrm{NH}_{4}\right)_{2} \mathrm{SO}_{4}(70 \sim 90 \%)$ & 1,680 & 1,470 & 0.88 & 23.1 \\
DEAE-Sephadex & 108 & 1,270 & 11.8 & 20.0 \\
Bio-Gel P-100 & 16.3 & 1,100 & 67.5 & 17.3 \\
Hydroxylapatite & 3.16 & 657 & 208 & 10.3 \\
\hline
\end{tabular}

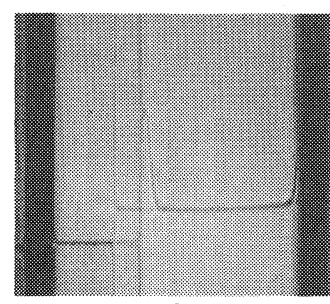

A

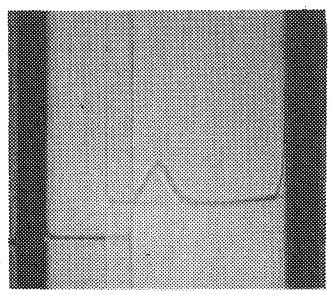

C

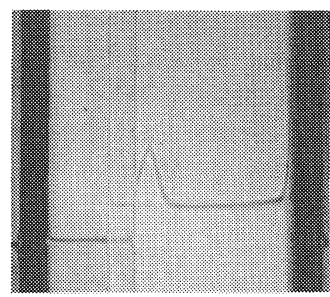

$\mathbf{B}$

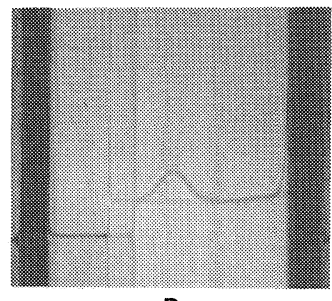

D

FIG. 1. Sedimentation Patterns of Glutathione Peroxidase from Mucor hiemalis.

The purified enzyme was used at a concentration of $4.1 \mathrm{mg}$ protein $/ \mathrm{ml}$ in $0.01 \mathrm{M}$ phosphate buffer, $\mathrm{pH} 6.0$, containing $0.1 \mathrm{M} \mathrm{KCl}$. Photographs were taken, $\mathrm{A}$ to $\mathrm{D}$, at $6,24,48$ and $72 \mathrm{~min}$ after reaching $55,430 \mathrm{rpm}$.

composition of glutathione peroxidase is shown in Table II. The results show that the enzyme has about 340 amino acid residues per mol and that it is rich in aspartic acid, glutamic acid and leucine. From the amino acid composition, the partial specific volume of the enzyme was calculated to be about 0.74 $\mathrm{cm}^{3} \mathrm{~g}^{-1}$ according to the method of Cohn and Edsall. ${ }^{9)}$

Molecular weight. The molecular weight of glutathione peroxidase was determined to be 45,000 by gel filtration on Sephadex G-150 (Fig. 2). SDS-polyacrylamide gel electrophoresis gave a single protein band with a mobility corresponding to a molecular weight
Table II. Amino Acid Composition of Glutathione Peroxidase from $M$. hiemalis

\begin{tabular}{|c|c|c|}
\hline Amino acid & $\begin{array}{l}\text { Analyzed value }^{a} \\
(\mu \mathrm{mol} / \mathrm{mg})\end{array}$ & $\begin{array}{l}\text { Nearest integer } \\
\text { (residues } / \mathrm{mol} \text { ) }\end{array}$ \\
\hline Lysine & 0.684 & 31 \\
\hline Histidine & 0.180 & 8 \\
\hline Arginine & 0.138 & 6 \\
\hline Aspartic acid & 1.05 & 47 \\
\hline Threonine & 0.470 & 21 \\
\hline Serine & 0.495 & 22 \\
\hline Glutamic acid & 0.843 & 38 \\
\hline Proline & 0.521 & 23 \\
\hline Glycine & 0.479 & 22 \\
\hline Alanine & 0.584 & 26 \\
\hline Half-cystine $^{b}$ & N.D. & N.D. \\
\hline Valine & 0.512 & 23 \\
\hline Methionine & 0 & 0 \\
\hline Isoleucine & 0.305 & 14 \\
\hline Leucine & 0.793 & 36 \\
\hline Tyrosine & 0.088 & 4 \\
\hline Phenylalanine & 0.412 & 19 \\
\hline Tryptophan $^{b}$ & N.D. & N.D. \\
\hline Total & & 340 \\
\hline
\end{tabular}

a Analytical methods are described in Methods.

$b$ Not determined.

of 27,000 (Fig. 3). These results suggest that the enzyme consists of two apparently identical subunits.

Isoelectric points. The isoelectric point of glutathione peroxidase was estimated to be 5.2 by isoelectric focusing (Fig. 4).

Effect of $p H$. The effect of $\mathrm{pH}$ on the activity and stability of glutathione peroxidase was examined. The enzyme activity was maximum at around $\mathrm{pH} 6.0$ as shown in Fig. 5. The enzyme was stable between $\mathrm{pH} 5.0$ and 7.0 on treatment at $4^{\circ} \mathrm{C}$ for $24 \mathrm{hr}$.

Thermostability. The effect of temperature 


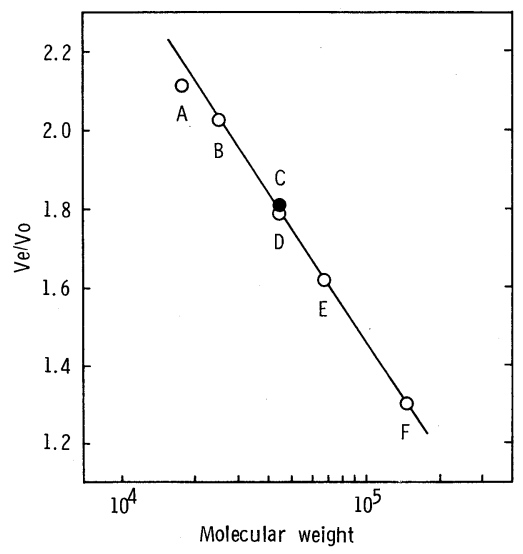

FIG. 2. Determination of Molecular Weight of Glutathione Peroxidase by Sephadex G-150 Gel Filtration.

Experimental conditions are described in Methods. A, myoglobin; B, chymotrypsinogen; $\mathrm{C}$, glutathione peroxidase; D, ovalbumin; E, bovine serum albumin; F, alcohol dehydrogenase. $V o$ and $V e$ are the void volume of the column and the elution volume of protein, respectively.

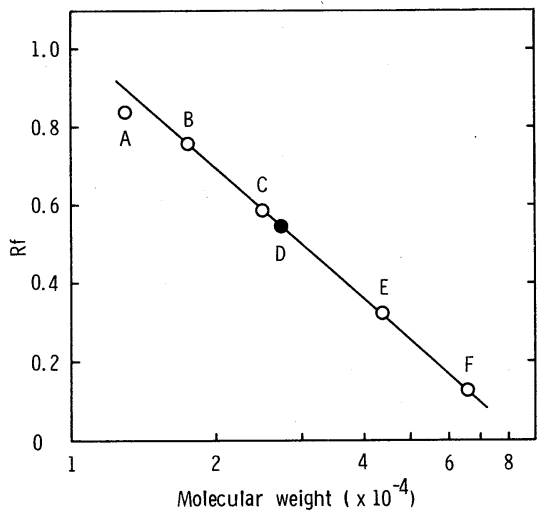

FIG. 3. Determination of Molecular Weight of Glutathione Peroxidase by SDS-Polyacrylamide Gel Electrophoresis.

Experimental conditions are described in MEthods. A, cytochrome $c$; B, myoglobin; C, chymotrypsinogen; D, glutathione peroxidase; E, ovalbumin; F, bovine serum albumin.

on the stability of glutathione peroxidase was tested. The enzyme was stable up to $50^{\circ} \mathrm{C}$ when treated at $\mathrm{pH} 6.0$ for $15 \mathrm{~min}$, and lost about $55 \%$ of the original activity at $60^{\circ} \mathrm{C}$.

Substrate specificity. The substrate specificity of glutathione peroxidase was determined for several hydroperoxide and sulfhydryl substrates. Cumene hydroperoxide was

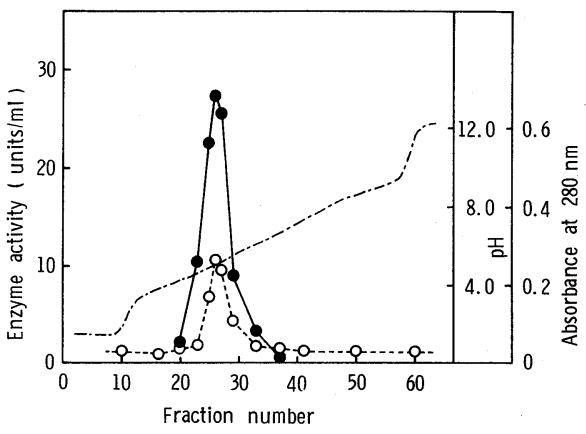

FIG. 4. Isoelectric Focusing of Glutathione Peroxidase. Purified protein $(6 \mathrm{mg})$ was applied to an isoelectric focusing column of $110 \mathrm{ml}$. The conditions for electrophoresis are described in METHODs. glutathione peroxidase activity; $\bigcirc$, absorbance at $280 \mathrm{~nm} ;---, \mathrm{pH}$.

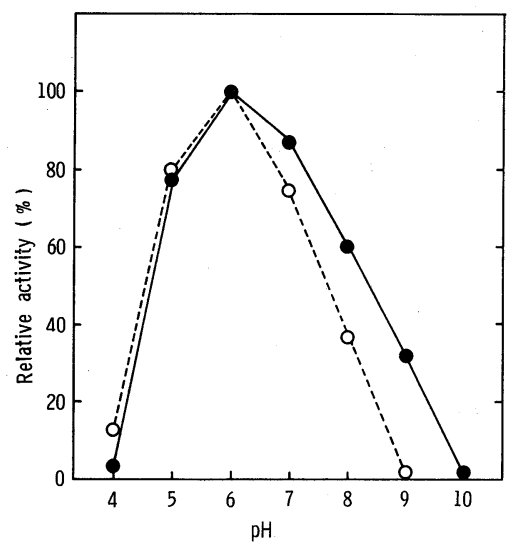

FIG. 5. Effect of $\mathrm{pH}$ on the Activity of Glutathione Peroxidase.

The enzyme activity was determined by two assay methods, namely, the coupled enzymatic method (O) and the DTNB method (O), under the respective standard conditions with the $0.05 \mathrm{M}$ buffer indicated. Acetate buffer was used from $\mathrm{pH} 4.0$ to 5.0, phosphate buffer from $\mathrm{pH} 6.0$ to 8.0 , and borate buffer from $\mathrm{pH} 9.0$ to 10 .

most effectively reduced, and $t$-butyl hydroperoxide showed about $90 \%$ of the enzymatic reaction rate with cumene hydroperoxide (Table III). On the other hand, the enzyme did not act on hydrogen peroxide or dialkyl peroxides (R-00-R) such as dicumene peroxide and di- $t$-butyl peroxide. The enzyme was highly specific for glutathione as a hydrogen donor, and other sulfhydryl compounds tested were not effective at all (Table IV). The apparent $\mathrm{Km}$ values for cumene hydroperoxide, $t$-butyl 
Table III. Substrate Specificity of Glutathione Peroxidase In the REDUCTION OF VARIOUS HYDROPEROXIDES

The rates of reduction were determined by the coupled enzymatic method (I) and were expressed as a percentage of that of cumene hydroperoxide.

\begin{tabular}{lc}
\hline \multicolumn{1}{c}{ Substrate } & Relative activity $(\%)$ \\
\hline Cumene hydroperoxide & 100 \\
$t$-Butyl hydroperoxide & 90.1 \\
Hydrogen peroxide & 0 \\
Dicumene peroxide & 0 \\
Di- $t$-butyl peroxide & 0
\end{tabular}

Table IV. Substrate Specificity of Glutathione Peroxidase IN The HYDROGEN DONOR

The enzyme activity was assayed by the DTNB method (II), and was expressed in $\mu \mathrm{mol}$ of sulfhydryl residue oxidized per min.

\begin{tabular}{lc}
\hline Thiol compound & Activity \\
\hline Glutathione & 36 \\
L-Cysteine & 0 \\
Dithiothreitol & 0 \\
2-Mercaptoethanol & 0 \\
Cysteamine & 0 \\
Thioglycolic acid & 0 \\
\hline
\end{tabular}

hydroperoxide and glutathione were calculated to be $0.13 \mathrm{~mm}, 0.13 \mathrm{~mm}$ and $0.67 \mathrm{~mm}$, respectively. Mucor glutathione peroxidase did not show glutathione $S$-transferase activity, as described previously. ${ }^{1)}$

Effect of various chemicals. The effect of various chemicals on the activity of glutathione peroxidase was examined (Table V). Various kinds of chelating agents did not affect the enzyme activity. This suggests that metal ions are not concerned in the enzyme activity directly. Anionic detergents such as SDS and bile acids inhibited the enzyme activity strongly, whereas non-ionic detergents did not affect the enzyme activity. Of divalent cations tested, only the cupric ion was inhibitory. ATP, which is an allosteric inhibitor for mammalian selenium-dependent glutathione peroxidase $\mathrm{I},{ }^{10}$ ) and bilirubin, which is a potent inhibitor for glutathione $S$-transferase, ${ }^{11)}$ did
TABLE V. EFFECT OF VARIOUS Chemicals on the Activity of Glutathione Peroxidase

The enzyme was incubated in $50 \mathrm{~mm}$ phosphate buffer, $\mathrm{pH} 7.0$, containing various chemicals for $15 \mathrm{~min}$ at $25^{\circ} \mathrm{C}$. Then, the reaction was initiated by addition of cumene hydroperoxide. Activities were determined by the coupled enzymatic method (I) or the DTNB method (II) $(*)$, and were expressed as a percentage of the case of no addition, respectively. In this experiment, sodium azide and EDTA were omitted from both standard reaction mixtures.

\begin{tabular}{|c|c|c|}
\hline Chemical & Concentration & $\begin{array}{l}\text { Relative } \\
\text { activity }\end{array}$ \\
\hline No addition & - & 100 \\
\hline No addition & - & $100 *$ \\
\hline EDTA & $1 \mathrm{~mm}$ & 106 \\
\hline$o$-Phenanthroline & $1 \mathrm{~mm}$ & 110 \\
\hline$\alpha, \alpha^{\prime}$-Dipyridyl & $1 \mathrm{~mm}$ & 102 \\
\hline $\begin{array}{l}\text { Diethyldithiocarbamic } \\
\text { acid }\end{array}$ & $1 \mathrm{~mm}$ & 114 \\
\hline$o$-Phenylenediamine & $1 \mathrm{~mm}$ & 104 \\
\hline $\mathrm{KCN}$ & $1 \mathrm{~mm}$ & 105 \\
\hline $\mathrm{NaN}_{3}$ & $1 \mathrm{~mm}$ & 112 \\
\hline Hydroxylamine & $1 \mathrm{~mm}$ & 117 \\
\hline \multirow[t]{2}{*}{ Iodoacetic acid } & $0.1 \mathrm{~mm}$ & 95.9 \\
\hline & $1 \mathrm{~mm}$ & 64.8 \\
\hline \multirow[t]{2}{*}{ Iodoacetamide } & $0.1 \mathrm{~mm}$ & 98.9 \\
\hline & $1 \mathrm{~mm}$ & 84.3 \\
\hline Chlortetracycline & $1 \mathrm{~mm}$ & $102 *$ \\
\hline Quinacrine & $1 \mathrm{~mm}$ & $82.4^{*}$ \\
\hline Sodium dodecyl sulfate & $0.1 \%$ & $1.0^{*}$ \\
\hline Cholic acid & $0.1 \%$ & 37.4 \\
\hline Deoxycholic acid & $0.1 \%$ & 18.3 \\
\hline Triton X-100 & $0.1 \%$ & 84.6 \\
\hline Tween 40 & $0.1 \%$ & 100 \\
\hline Span 40 & $0.1 \%$ & 99.0 \\
\hline $\mathrm{CuSO}_{4}$ & $1 \mathrm{mM}^{\circ}$ & 33.0 \\
\hline $\mathrm{FeSO}_{4}$ & $1 \mathrm{~mm}$ & $87.5^{*}$ \\
\hline ATP & $1 \mathrm{~mm}$ & 104 \\
\hline Bilirubin & $0.02 \mathrm{~mm}$ & 90.5 \\
\hline
\end{tabular}

not inhibit this microbial glutathione peroxidase.

\section{DISCUSSION}

Glutathione peroxidase from Mucor hiemalis was purified to homogeneity. The specific activity of the final preparation was 208 units/mg protein. The specific activities of purified selenium-dependent glutathione peroxidases I were reported to be $41.8,103,123$, $70.4,1036$ and 1852 units/mg for bovine lens 
Table VI. Properties of Glutathione Peroxidase of Various Origins

Physicochemical and enzymatic properties of three kinds of glutathione peroxidases were compared.

\begin{tabular}{|c|c|c|c|}
\hline & Mucor GSH-Px ${ }^{a}$ & GSH-Px I ${ }^{b}$ & GSH-Px II ${ }^{b}$ \\
\hline Se content (atoms $/$ mole) & 0 & 4 & 0 \\
\hline Molecular weight & 45,000 & $75,000 \sim 96,600$ & $39,000 \sim 45,000$ \\
\hline Subunit number & 2 & 4 & 2 \\
\hline Isoelectric point & 5.2 & $4.9 \sim 7.0$ & $8.5 \sim 9.5$ \\
\hline \multicolumn{4}{|l|}{ Substrate specificity } \\
\hline Reduction of $\mathrm{H}_{2} \mathrm{O}_{2}$ & No & Yes & No \\
\hline Transferase activity & No & No & Yes \\
\hline \multicolumn{4}{|l|}{ Michaelis constant } \\
\hline Cumene hydroperoxide & $0.13 \mathrm{~mm}$ & $0.027 \sim 0.08 \mathrm{mM}$ & $0.18 \sim 0.57 \mathrm{~mm}$ \\
\hline Glutathione & $0.67 \mathrm{~mm}$ & $0.017 \sim 0.13 \mathrm{mM}$ & $0.2 \mathrm{~mm}$ \\
\hline pH Optimum & 6.0 & $8.5 \sim 9.1$ & N.D. ${ }^{c}$ \\
\hline \multicolumn{4}{|c|}{ a $\quad$ Glutathione peroxidase from $M$. hiemalis. } \\
\hline \multicolumn{4}{|c|}{$\begin{array}{l}\text { Glutathione peroxidases I and II of various mammalian origins, and their properties are cited from many } \\
\text { reports described in the text. }\end{array}$} \\
\hline
\end{tabular}

enzyme, ${ }^{12)}$ human erythrocyte enzyme, ${ }^{13)}$ rat liver mitochondrial enzyme ${ }^{14)}$ and rat liver cytosolic enzymes, ${ }^{15 \sim 17)}$ respectively. The specific activities of purified selenium-independent glutathione peroxidases II were also reported to be 5.07, 8.0 and 11 units/mg for human liver enzyme, ${ }^{18)}$ guinea pig liver enzyme ${ }^{19)}$ and rat liver enzyme, ${ }^{20)}$ respectively. The specific activity of Mucor glutathione peroxidase was close to those of selenium-dependent glutathione peroxidases I.

When the properties of Mucor glutathione peroxidase were compared with those of mammalian glutathione peroxidases I and II, ${ }^{21 ~ 25)}$ this microbial enzyme was found to be different from the two mammalian enzymes in some physicochemical and enzymatic properties, as summarized in Table VI. The important characteristics of Mucor glutathione peroxidase were that it is selenium-independent and does not show glutathione $S$-transferase activity. From these results, we concluded that the Mucor glutathione peroxidase is a novel type of enzyme.

The following peroxidases are known at present: protoheme peroxidases and flavoprotein peroxidases. ${ }^{26)}$ Mucor glutathione peroxidase was suggested to contain no heme because it had no Soret band at $400 \sim 420 \mathrm{~nm}$ (data not shown) and was insensitive to azide and cyanide inhibition, and X-ray fluorescence analysis failed to detect a significant amount of iron as described previously. ${ }^{1)}$ No inhibition by quinacrine or chlortetracycline, both inhibitors of flavoenzymes, ${ }^{27)}$ suggest that a flavin nucleotide is not involved in the Mucor enzyme activity. It remains unknown what moiety in the Mucor enzyme is concerned in the oxidation-reduction reaction. Further characterization of the Mucor glutathione peroxidase is now underway.

Acknowledgment. The authors wish to thank Miss Kyoko Kamezaki for her excellent assistance.

\section{REFERENCES}

1) K. Aisaka, T. Uwajima and O. Terada, Agric. Biol. Chem., 46, 3113 (1982).

2) K. Aisaka, T. Uwajima and O. Terada, Agric. Biol. Chem., 47, 1269 (1983).

3) J. Sedlak and R. H. Lindsay, Anal. Biochem., 25, 192 (1968).

4) O. H. Lowry, N. J. Rosebrough, A. L. Farr and R. J. Randall, J. Biol. Chem., 193, 265 (1951).

5) P. Andrews, Biochem. J., 91, 222 (1964).

6) K. Weber and M. Osborn, J. Biol. Chem., 244, 4406 (1969).

7) O. Vesterberg and H. Svensson, Acta Chem. Scand., 20, 820 (1966).

8) A. Tiselius, S. Hjerten and O. Levin, Arch. Biochem. Acta, 20, 435 (1967).

9) E. J. Cohn and J. T. Edsall, "Proteins, Amino Acids 
and Peptides," Reinhold, New York, 1943, p. 370.

10) C. Little, R. Olinescu, K. G. Reid and P. T. O'Brien, J. Biol. Chem., 245, 3632 (1970).

11) J. N. Ketley, W. H. Habig and W. B. Jakoby, J. Biol. Chem., 250, 8670 (1975).

12) N. J. Holmberg, Exptl. Eye Res., 7, 570 (1968).

13) Y. C. Awasthi, E. Beutler and S. K. Srivastava, J. Biol. Chem., 250, 5144 (1975).

14) J. J. Zakowski and A. L. Tappel, Biochim. Biophys. Acta, 526, 65 (1978).

15) W. Nakamura, S. Hosoda and K. Hayashi, Biochim. Biophys. Acta, 358, 251 (1974).

16) S. Yoshimura, N. Komatsu and K. Watanabe, Biochim. Biophys. Acta, 621, 130 (1980).

17) M. Yoshida, K. Iwami and K. Yasumoto, Agric. Biol. Chem., 46, 41 (1982).

18) Y. C. Awasthi, D. D. Dao and R. P. Saneto, Biochem. J., 191, 1 (1980).

19) C. Irwin, J. K. O’Brien, P. Chu, J. K. TownsendParchman, P. O’Hara and F. E. Hunter, Jr., Arch.
Biochem. Biophys., 205, 122 (1980).

20) J. R. Prohaska, Biochim. Biophys. Acta, 611, 87 (1980).

21) A. Wendel, "Enzymatic Basis of Detoxication," Vol. I, Academic Press Inc., New York, N. Y., 1980, p. 333.

22) R. A. Lawrence and R. F. Burk, Biochem. Biophys. Res. Commun., 71, 952 (1976).

23) J. R. Prohaska and H. E. Ganther, Biochem. Biophys. Res. Commun., 76, 437 (1977).

24) M. R. Shreve, P. G. Morrissey and P. T. O'Brien, Biochem. J., 177, 761 (1979).

25) P. Morrissey and P. T. O'Brien, Can. J. Biochem., 58, 1012 (1980).

26) K. G. Paul, "The Enzymes," Vol. 8, 2nd Ed., ed. by P. D. Boyer, H. Lardy and K. Myrback, Academic Press Inc., New York, N. Y., 1963, p. 227.

27) J. Roberts and H. J. Rosenfeld, J. Biol. Chem., 252, 2640 (1977). 